高分子踚文集 (Kobunshi Ronbunshu)，Vol. 36, No. 5, pp. 321-327 (May, 1979)

\title{
ポリ塩化ビニルーエトキシメチル化メラミン樹脂の ブレンド物の動的粘弾性
}

\author{
田中 勝敏*1 ・ 小川 弘正*1 ・田中 裕子*1
}

(受付 1978 年 11 月 13 日・著查終了1978 年 11 月 25 日)

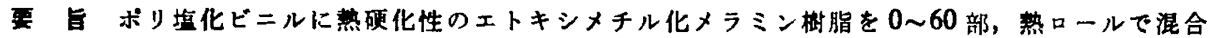

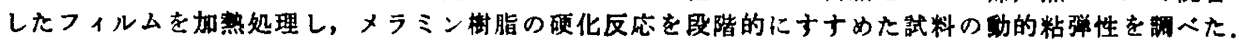

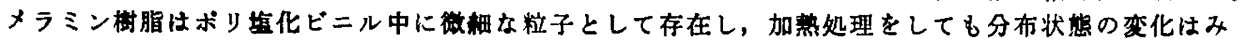
られない，メラミン㯕脂の硬化反态をすすめていくと，充てん材を增していくよ5に弹性事は增加し，

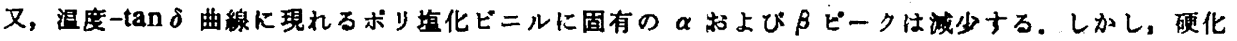
反応による脱離分子のホルムてルデヒドおよびェタノールによって，ボリ塩化ビニル注可塑化され， ガラス枟移沮度仙低下する。これらの現象はメラミン㯕脂の添加量が多くなる任と影著になるが，こ の混合系はボリ场化ビニルに充てん材と可塑郕とを添加したものとして，その粘强性举動をモテルを 用いて説明した。
\end{abstract}

\section{1 棈}

ポリマーブレンドはそれぞれのポリマーの性能を相補 らにとどまらず，それ以上の性能を得ることがあるため に，多くの研究がなされている。 そしてポリマーブレン ドの混合状㮩を解明する手段として，粘弾性測定は有効

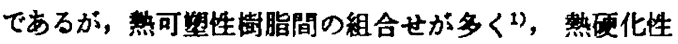
樹脂と熱可塑性樹脂との組合せは，フェノール樹脂のぜ い性を悢和するためのポリビニルブチラールとの和， エボキシ樹脂の強物性を增加させるための液状ゴムとの 采などにみられるだけである。

ガラス織維強化ボリ塩化ビニルに関しては，強化材と してのガラス織維とポり塩化ビニルとの親和性を增加す るために, シラン禾などのカップリング詴が使用されて いるが, アルコキシメチル化メラミン榯脂はカラスとの

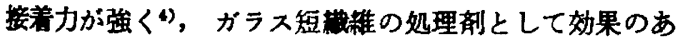
ることが知られている゙．

ここで惊り塩化ピニルとェトキシメチル化メラミン 椥脂との熱口ールによる機械的なブレンド物について, エトキシメチル化メラミン樹脂の硬化度と動的粘弾性と の関保について得た知見を報告する。

\section{2 実医}

\section{1 域料}

ポリ塩化ピニル (PVC, 平均重合度 800：日本ゼオン (株) 103EP8) 100 部に対し, 安定剂のジフチルスズ マレェートを4部および浻剂のブチルステフレートを
0.5 部加えたものを基隼配合とし、エトキシメチル化メ ラミン樹脂 (EMR) はそれぞれ 0,10，25，40，および 60 部加えた. これらを $160 \sim 165^{\circ} \mathrm{C}$ の熱口ールで混合 し,ホットブレス $\left(160^{\circ} \mathrm{C}\right)$ して厚さ $0.2 \mathrm{~mm}$ のフィル ムとした (C-160, C は 0, 10, 25, 40, および 60). 熱処理試料はホットブレスを使用しこれらのフィルム

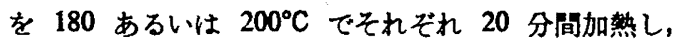
EMR の硬化反応を促進させて調整した (C-180および 200).

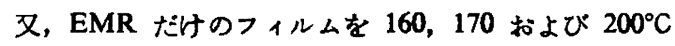
でそれぞれ 20 分間, ホットブレスして作成した（100T, T は 160，170，および 200)。なお，すへての陚料 は $60^{\circ} \mathrm{C}$ で3時間フニーリンクした後, 室温で重量変化 がなくなるまで減圧䩪嬠した。

\section{2 測定}

EMR の混合状態を調べるために，走查型䉓子䫒微鏡 (MSM，（株) 明石製作所製) を使用し，試料の破断面を 観察した。

EMR の便化反応がどの段階にあるかを調へてるた 二, 示差熱分析测定 (DTA) を熱分析装置卓上型 8001 (理学電気 (株) 製) を使用し, 昇温速度 $10^{\circ} \mathrm{C} / \mathrm{min}$ で行 った. 又, 熱処理による塩素含有率変化を然烧フラスコ 法により調べた。

動的粘弾性測定は, 口ール方向に長さ約 $70 \mathrm{~mm}$, 愊 $2 \mathrm{~mm}$ に切った陚料片について, Vibron DDV-IIB (東 洋ボールドゥイン(株)製)を使用して，温度笽囲 -100 $200^{\circ} \mathrm{C}$, 振動数 $110 \mathrm{~Hz}$, 昗温速度 $1^{\circ} \mathrm{C} / \mathrm{min}, 1 \sim 3^{\circ} \mathrm{C}$ の間 隔で行った. 詝藏弾性率 $\left(E^{\prime}\right)$ および損失弹性率 $\left(E^{\prime \prime}\right)$ 
田中・小川・田中

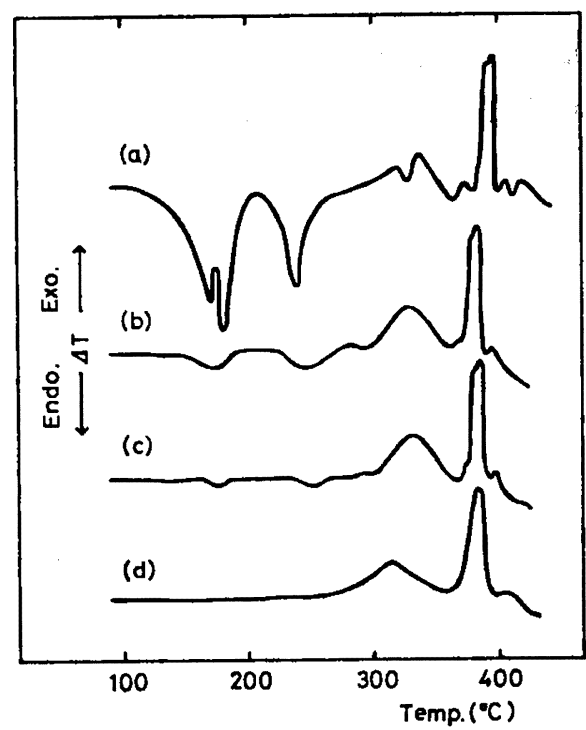

Fig. 1. DTA curves of ethoxymethylmelamine resin at various heat-treatment temperatures: (a), untreated; (b), No. $100-160 ;$ (c), 100170; (d), 100-200.

を計算する際には装居およひ試料の末端に対する補正の を行った。 また $25^{\circ} \mathrm{C}$ の密度も測定した。

\section{3 結果と考察}

\section{1 战料}

ここで使用した EMR は, メラミン, ホルムフルデ ヒドおよびェタノールのモル比を $1: 7: 14$ とし, 循謤 脱水方式》で得たもので，次のような構造8)である.10 個のXは 2 個の水来，4個のメチロ一ル基および 4 個の<smiles>[X][M]CN=C1N=C([Y14])NC([Y14])N1</smiles>

$2 \mathrm{X},-\mathrm{H} ; 4 \mathrm{X},-\mathrm{CH}_{2} \mathrm{OH} ; 4 \mathrm{X},-\mathrm{CH}_{2} \mathrm{OC}_{2} \mathrm{H}_{5}$ エトキシメチル基である.

この EMR は加熱すると硬化反応が促進され，2

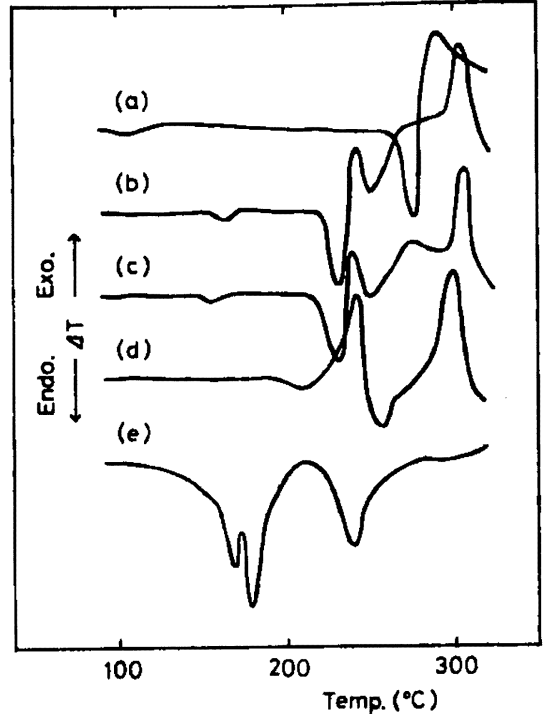

Fig. 2. DTA curves of blends of poly (vinyl chloride) and ethoxymethylmelamine resin at various heat-treatment temperatures: (a), No. $0-160$; (b), 60-160; (c), 60-180; (d), 60-200; (e), ethoxymethylmelamine resin (untreated)

体から高分子になっていくが，Fig. 1 に DTA 測定の 結果を示す， 2 量体の DTA 曲線仙恃， $168^{\circ} \mathrm{C}$ (反応 I), $176^{\circ} \mathrm{C}$ (反応 II) およひ $240^{\circ} \mathrm{C}$ (反応 III) の硬化反応を 示す 3 個の吸熱ピークがみられる. 反応Ｉでは，おむに 水およびホルムフルデヒド，反応 II ではェタノール， 反応 III ではェタノールおよび水が脱離分子として検出 されるり．100-160では反応おおよびIかかかなり進み， 反応 III も多少始まっている. 100-170 では反応 I, II および III は 100-160 上りも進んでおり，100-200で は3 個の反応恃はとんど終了している、一方，PVCの DTA 測定の結果（Fig. 2) をみると，0-160では $100^{\circ} \mathrm{C}$ 付近の小さなビークと, $275^{\circ} \mathrm{C}$ 付近の大きなビークがあ り, 前者は PVC のガラス転移に, 後者は塩化水素を伴 う熱分解によるものである ${ }^{10)}$. 0-180 および0-200は 0-160 とほとんど変わらない挙動を示した. 次にブレ ンド試料についてみると，EMR に特有な吸熟ピークが 現れている. 60-160 では反応 I およびII の小さなピ 一クがみられ，反応 III はまだ進んでいない，60-180 では反応 I および II は根跡程度であるが，反応 III は それはど進んでいない，そして 60-200 では反応】施 よび II は終了し，反応 III もかなり進んだ状態にあ ろ.な扰 10-T, 25-T および 40-T の結果も 60-T と同 しょうな硬化反応の進行を示した．このことは塩菜含有 率の測定結果 (Table 1) Kおいても，0-200は 0-160 
ボリ㨁化ビニルーエトキシメチル化メラミン橵脂のフレンド物の功的粘弹性

Table 1. Component, heat-tretment temperature, and physical properties of blends of PVC and EMR

\begin{tabular}{|c|c|c|c|c|c|c|}
\hline \multirow[b]{2}{*}{ Code } & \multicolumn{2}{|c|}{ Component } & \multirow{2}{*}{$\begin{array}{l}\text { Heat-treat- } \\
\text { ment temp. } \\
\left({ }^{\circ} \mathrm{C}\right)\end{array}$} & \multirow{2}{*}{$\begin{array}{c}\text { Chlorine } \\
\text { content } \\
(\%)\end{array}$} & \multirow{2}{*}{$\begin{array}{l}\text { Density } \\
(\mathrm{g} / \mathrm{m} l)\end{array}$} & \multirow{2}{*}{$\begin{array}{l}\left.T_{\mathrm{E}} \mathrm{b}\right) \\
\left({ }^{\circ} \mathrm{C}\right)\end{array}$} \\
\hline & $\begin{array}{c}\text { PVCa) } \\
(\mathbf{8})\end{array}$ & $\begin{array}{c}\text { EMR } \\
(\mathrm{g})\end{array}$ & & & & \\
\hline $0-160$ & 104.5 & 0 & 160 & 51.9 & 1.399 & 100.0 \\
\hline $0-180$ & 104.5 & 0 & 180 & - & 1.399 & 100.0 \\
\hline $0-200$ & 104.5 & 0 & 200 & 51.1 & 1.398 & 99.0 \\
\hline $10-160$ & 104.5 & 10 & 160 & - & 1.378 & 97.0 \\
\hline $10-180$ & 104.5 & 10 & 180 & - & 1.387 & 93.5 \\
\hline $10-200$ & 104.5 & 10 & 200 & - & 1.391 & 90.0 \\
\hline $25-160$ & 104.5 & 25 & 160 & 43.9 & 1.362 & 98.5 \\
\hline $25-180$ & 104.5 & 25 & 180 & - & 1.375 & 94.0 \\
\hline $25-200$ & 104.5 & 25 & 200 & 43.3 & 1.381 & 87.0 \\
\hline $40-160$ & 104.5 & 40 & 160 & - & 1.352 & 100.0 \\
\hline $40-180$ & 104.5 & 40 & 180 & - & 1.367 & 94.0 \\
\hline $40-200$ & 104.5 & 40 & 200 & - & 1.375 & 84.5 \\
\hline $60-160$ & 104.5 & 60 & 160 & 36.6 & 1.345 & 101.0 \\
\hline $60-180$ & 104.5 & 60 & 180 & - & 1.360 & 94.5 \\
\hline $60-200$ & 104.5 & 60 & 200 & 36.9 & 1.370 & 81.5 \\
\hline $100-160$ & 0 & 100 & 160 & - & 1.244 & 125.0 \\
\hline $100-170$ & 0 & 100 & 170 & - & 1.243 & 145.0 \\
\hline $100-200$ & 0 & 100 & 200 & - & - & - \\
\hline
\end{tabular}

*) Weight of PVC, stabilizer, and lubricant. b) Temperature of maximum of $\alpha$-peak.

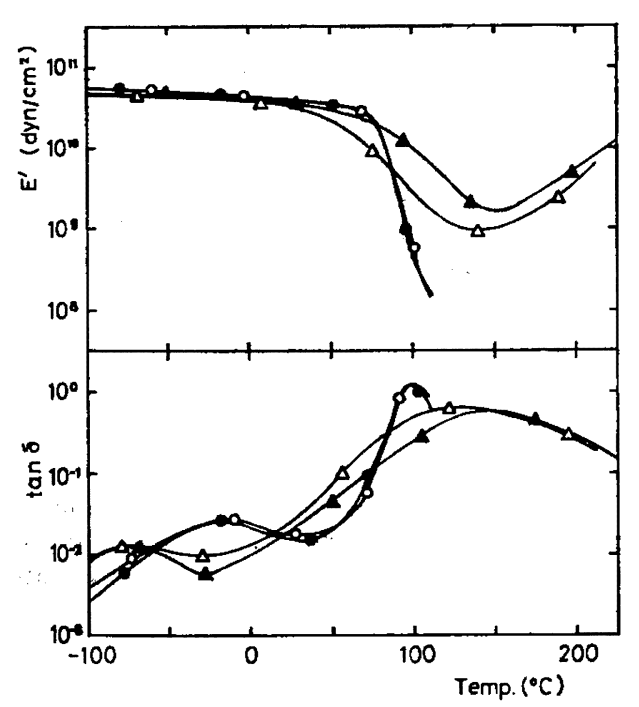

Fig. 3. Temperature dependence of storage modulus and $\tan \delta$ of poly (vinyl chloride) and ethoxymethylmelamine resin heat-treated at various temperatures: $O$, No. $0-160 ; 0,0$ $200 ; \Delta, 100-160 ; \Delta, 100-170$.
よりも小さな值を示すが，脱塩化水素反応によるもので ある. ブレンド試料では, $25-\mathrm{T}$ は $200^{\circ} \mathrm{C}$ の熱処理をし ても塩素含有率はやや減少しているが，60-T ではかえ って增加している．これは PVC の脱塩化水素反応によ る減少よりも，EMR の硬化反応沉よって生成した脱唯 分子による減量の方が大きいためである。

\section{2 功的粘弾性}

0-Tおよび 100-T の動的粘弾性が熟処理によってど

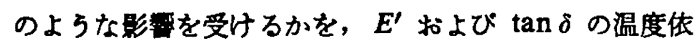
存性からみる (Fig. 3)，0-160 の $E^{\prime}$ 曲線に任低温域 の大きな弾性率をむつガラス領域から， $100^{\circ} \mathrm{C}$ 付近で弾

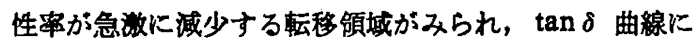
は低温の小さくフィードな $\beta$ ピークと $100^{\circ} \mathrm{C}$ 付近の大 きくてシャープな $\alpha$ ピーク（極大となる温度を $T_{\text {\& }}$ とす るがみられる０-200るほとんど変わらない挙動を 示しており，PVC はこの程度の熱処理では粘弾性に対 する影密は小さい，一方，EMR の $E^{\prime}$ 曲線には低温の ガラス領域, $30^{\circ} \mathrm{C}$ から $130^{\circ} \mathrm{C}$ までの広い温度域にわた 万転䅡域, そして湘定時の加熱で硬化反応が促進され ての弾性率の增加が高温度域にみられる. 又, $\tan \delta$ 曲 線には $-70^{\circ} \mathrm{C}$ 付近の小さなピーク, $140^{\circ} \mathrm{C}$ 付近で極大 となる大きくブロードなピークがみられる. EMR の場 合は熟処理の影響は大きく, 温度を $160^{\circ} \mathrm{C}$ から $170^{\circ} \mathrm{C}$ 


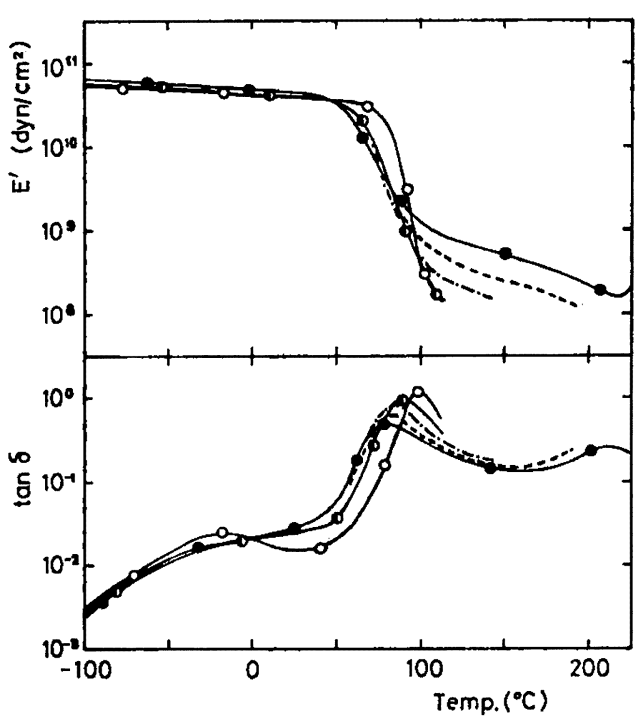

Fig. 4. Temperature dependence of storage modulus and $\tan \delta$ for specimens heat-treated at $160^{\circ} \mathrm{C}$ : $O$, No. $0-160$; D, $10-160 ;-\cdot-, 25-$ $160 ;-, 40-160 ; O, 60-160$.

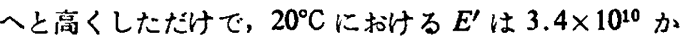
ら $3.7 \times 10^{10} \mathrm{dyn} / \mathrm{cm}^{2}$ へと增加し, $T_{\mathrm{g}}$ \& $125^{\circ} \mathrm{C}$ から $145^{\circ} \mathrm{C}$ 一と大きくシフトした. $200^{\circ} \mathrm{C}$ ではさらに大きな 変化が予想されるが， $180^{\circ} \mathrm{C}$ 以上の試料は非常にむろく なり，動的粘弾性測定は不可能であった.

次にブレンド試料の結果をみる.C-160 (Fig. 4) では EMR の勧が增加すると，PVC の举動に EMR の举娌 が加わっていく． $E^{\prime}$ 曲線ではガラス領城にはそれほど 影洛はみられないが，転移領城ではその勾配は悢やかに なっていく. $\tan \delta$ 曲線は低温のビークはしだに低く なって極大点をとらずに台地状となる。一方，高温のビ 一クは減少するが， $T_{k}$ は $100^{\circ} \mathrm{C}$ 付近にとどまってい る. C-200 では C-160 と異なった举動が第つかみられ る (Fig. 5). それは $\tan \delta$ 曲線に顕著で，低温のビ一 クはいずれる台地状になり， $T_{\mathrm{g}}$ はすへて $90^{\circ} \mathrm{C} よ り$ 低下 して EMR の是が多いほど低い温度となる，C-180 む C-200 と同様な挙動を示すが， $T_{\mathrm{B}}$ は $90 \sim 95^{\circ} \mathrm{C}$ の䉇用 にある (Fig. 6(a)).

ガラス領㳦である $20^{\circ} \mathrm{C}$ の $E^{\prime}$ の值と EMR の量と の成係 (Fig. 6(b)) をみる，0-T では熱処理温度が高く なるにしたがって弾性率はわずかであるが減少する。一 方, ブレンド試料では, EMR の量が C-160 では 25, C-180 では 35，そして C-200 では 50 部を樶大として， それ以上の添加量で娍少している。 また熱処理温度が高 いはど弾性率は大きくなるが，EMR の量が多いはど影

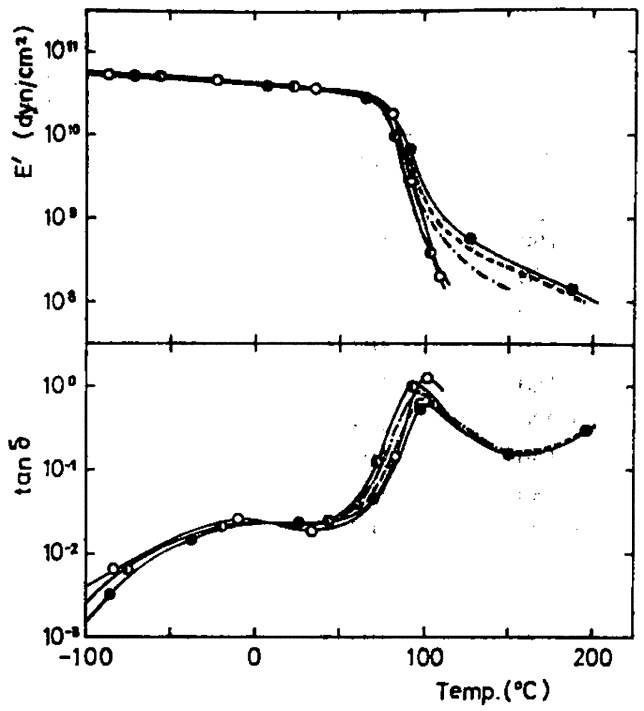

Fig. 5. Temperature dependence of storage modulus and $\tan \delta$ for specimens heat-treated at $200^{\circ} \mathrm{C}: \mathrm{O}$, No. $0-200 ;$ C, $10-200 ;-.-, 25-$ 200 ;,$- 40-200$; O, 60-200.

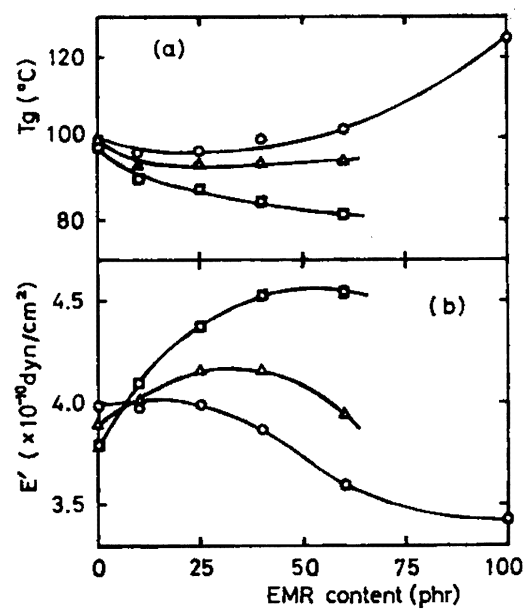

Fig. 6. Relation between ethoxymethyl melamine resin content and $T_{\mathrm{F}}$ (a), and storage modulus at $20^{\circ} \mathrm{C}(\mathrm{b})$, for the specimens heattreated at various temperatures: $0,160^{\circ} \mathrm{C} ; \Delta$, $180^{\circ} \mathrm{C} ; \square, 200^{\circ} \mathrm{C}$.

\section{著である.}

EMR の混合状態を破断面の写真 (Fig. 7) でみると， $160^{\circ} \mathrm{C}$ の熱ロールKよる機械的混合で EMR 怯，既に PVC のマトリックス中に 2〜10 $\mu \mathrm{m}$ の粒子となってお り (60-160), この試料を $200^{\circ} \mathrm{C}$ て加熱好理しても EMR 
ボリ塩化ビニルーエトキシメチル化メラミン樹脂のブレンド物の動的粘弾性
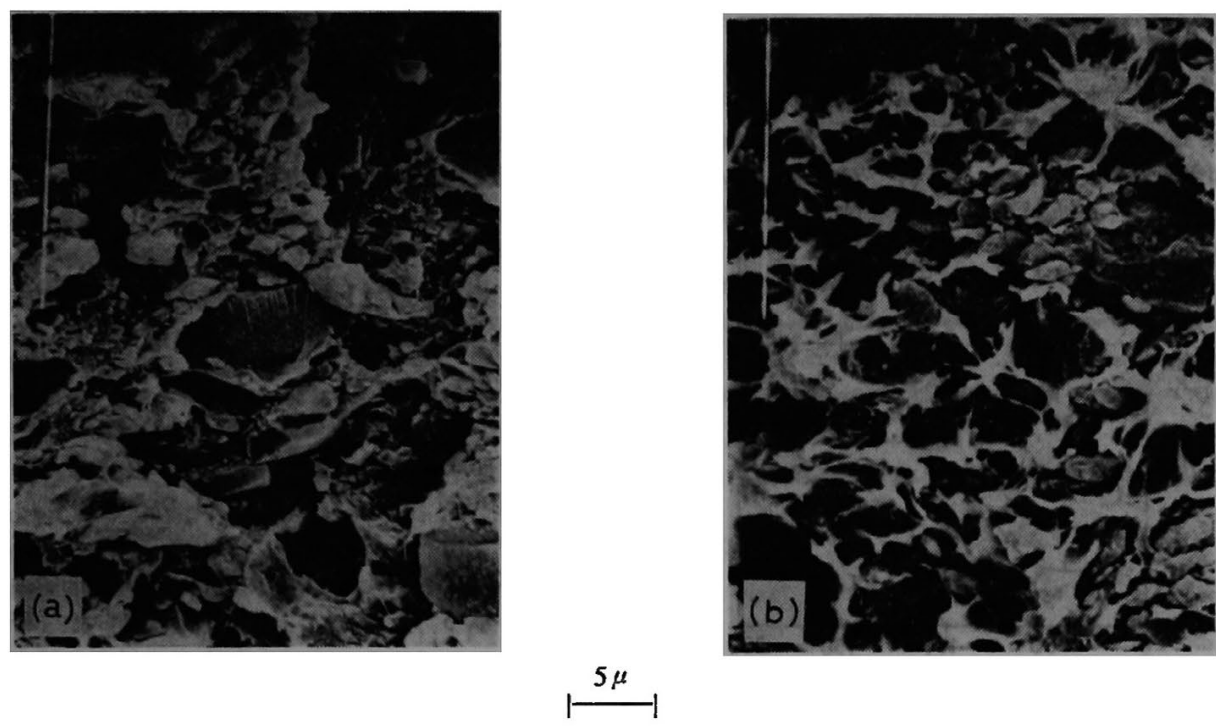

Fig. 7. SEM micro fractographs of blend of poly (vinyl chloride) and ethoxymethylmelamineresin: (a), No. 60-160; (b), 60-200. Magnification, 2000.

Table 2. Component and physical properties of blends of PVC, DOP, and glass fiber

\begin{tabular}{|c|c|c|c|c|c|}
\hline \multirow[b]{2}{*}{ Code } & \multicolumn{3}{|c|}{ Component } & \multirow{2}{*}{$\begin{array}{l}\text { Density } \\
(\mathrm{g} / \mathrm{m} l)\end{array}$} & \multirow{2}{*}{$\begin{array}{l}T_{\mathrm{g}}{ }^{\mathrm{e})} \\
\left({ }^{\circ} \mathrm{C}\right)\end{array}$} \\
\hline & $\begin{array}{c}\text { PVC }^{(a)} \\
(\mathrm{g})\end{array}$ & $\begin{array}{c}\text { DOP } \\
(\mathrm{g})\end{array}$ & $\begin{array}{l}\mathrm{GF}^{\mathrm{b})} \\
(\mathrm{g})\end{array}$ & & \\
\hline $0-160$ & 104.5 & 0 & 0 & 1.399 & 100.0 \\
\hline D-20 & 104.5 & 26.1 & 0 & 1.305 & 62.5 \\
\hline GF-20 & 104.5 & 0 & 20.0 & 1.511 & 105.0 \\
\hline D-GF & 104.5 & 26.1 & 20.0 & 1.396 & 64.0 \\
\hline
\end{tabular}

a) Weight of PVC, stabilizer, and lubricant. b) $6 \mathrm{~mm}$ chopped strand of glass fiber. c) Temperature of maximum of $\alpha$-peak.

の粒子の大きさや分布状態は変わっていない(60-200).

以上の点を総合して粘弾性の挙動をみると, EMR は 熱処理温度によって弾珄率の異なる充てん材の役割を果 し, EMR の硬化反応の際の脱離分子はマトリックスで ある PVC の可塑凧の役割を果していると考えられる. $160^{\circ} \mathrm{C}$ の熱ロールでブレンドするさい，180，あるいは $200^{\circ} \mathrm{C}$ の熱処理のさいに生成する脱離分子の水, ホル ムアルデヒドおよびェタノールの溶解度バラメーター (SP) はそれぞれ 23.4，12.9，および 12.7 と計算され る11).12). マトリックスの PVC の SP は 9.7 であり, ホルムアルデヒドおよびェタノールとは近い値をとる.

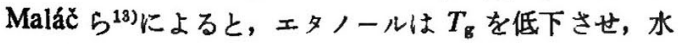
は $T_{\mathrm{g}}$ を高める効果を示している. ホルムアルデヒドは SP がェタノールとはとんど同じ SP 值をもつので，
タノールと同様な効果が期待される. そして Fig. 6(a) の EMR の量と $T_{\mathrm{g}}$ との関係においても明らかである が，EMR の量が一定のときには，熱処理温度が高くな ると $T_{\mathrm{g}}$ は低下していくが、この現象は EMR の量が多 いほど顕著である。

ここで充てん材と可塑郕との関係を調べるために， PVC-ガラス短織稚-2,4-ジェチルヘキシルフタレート (DOP, $\mathrm{SP}=8.9^{12)}$ ) の采をモデルに用いた。 ガラス短瀻 維は径 $9 \mu \mathrm{m}$, 長さ $6 \mathrm{~mm}$ の無了ルカリガラスで $625^{\circ} \mathrm{C} /$ $30 \mathrm{~min}$ のヒートクリーニンクしたものである。熱ロー ルでブレンドした武料 (Table 2) の動的粘弾性測定の 結果を Fig. 8 にしぬす，ガラス短織維の混入してない 試料 (D-20) は室温で既に転移領域にあって, $\tan \delta$ 曲 線の $\alpha$ ピークはプロードで $T_{\mathrm{g}}$ は $62.0^{\circ} \mathrm{C}$ 上低い. PVC 
田中・小川・田中

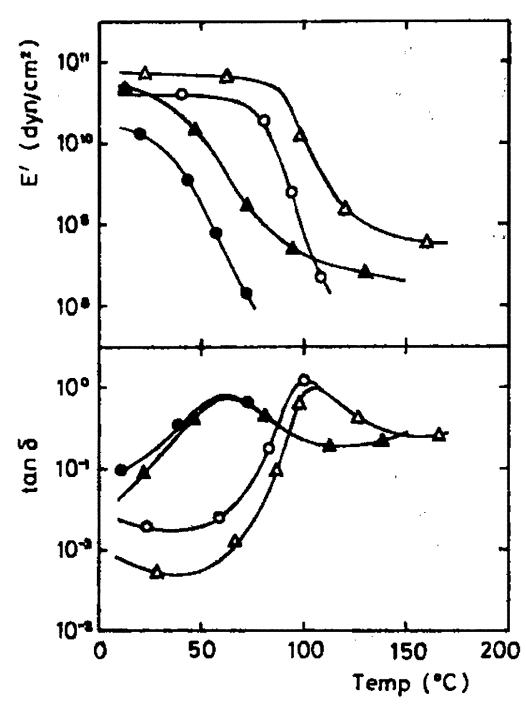

Fig. 8. Temperature dependence of storage modulus and $\tan \delta$ for plasticized and/or filled poly (vinyl chloride): $0,6-160 ; 0, \mathrm{D}-20 ; \Delta$, GF-20; $\triangle$, D-GF.

にガラス短㖑維のみを混入した試料 (GF-20) では， $E^{\prime}$ の值は測定温度籁囲すへてにわたって0-160よりも大 きく, $\tan \delta$ 曲線の $\alpha$ ビークは減少し， $T_{\mathrm{g}}$ は $105.0^{\circ} \mathrm{C}$ と高温となっている. PVC に DOP およびガラス短馀 維をブレンドした試料 (D-GF) では， $\mathrm{E}^{\prime}$ 曲線は室温に おいて D-20 と同様に転移領域にあってゆるやかなス口 ーブであるが, 高温では GF-20 のよ5に大きな値であ る. そして $\tan \delta$ 曲線には $\alpha$ ピークはやや低いが $T_{\mathbf{5}}$ は 64.0 とD-20 とほとんど同じ温度である。このよ5に 充てん材および可塑洬を加えた系では，転移領城の挙娌 は可塑剤の影繁が強く現れることが分かる. 又 PVCを EMR で処理したガラス短践維を充てんした陚料につい ても同侎な熱処理によって,ガラス領城では $E^{\prime}$ の值の 減少が, 転移領域では $\alpha$ ピークの隇少と $T_{\mathrm{g}}$ の低下が みられる ${ }^{14)}$.

\section{4 ま と}

PVC と EMR とのブレンド物を加熱処理し， EMR の硬化反応をいろいろな段階にすすめた試料について下 記のことが分かった。

(1) EMR は PVC マトリックス中に微細な粒子 (2 10 $\mu \mathrm{m})$ として分散している.
（2）加熱処理により EMR は硬化反応が促進せしめ られて原くなっていくが，分散状想は变わらない。そし て PVC は脱鹳分子により可整化される.

(3) その結果として, $\tan \boldsymbol{~} \boldsymbol{\beta}$ ピーク性台地状下

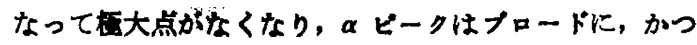
小さくなる. 又, $T_{\mathrm{g}}$ す低下する.

(4) $E^{\prime}$ については，ガラス領城ではその值はわず かではあるが剒加し，枟移領城では伀い温度械化広がっ てスローブは很やかになり，高温域でもEMRにより大 きな值をるつ。

(5) そして EMR が 60 部の試料 (60-T) では, 揤 定時の加热に上り，さらに硬化反応が促進されて $E^{\prime} の$ 增加 ( $\tan \delta$ でピークの成少) がみられる。

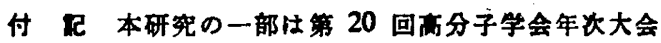
(1971 年 5 月，策京）に拈いて器表した。研究を進的 るにあたりこ将力いただいた本所高桶高子博士に厚く感 䂤する。

\section{文赫}

1) R. Buchdahl and L.E. Nielsen, J. Polym. Sci., 15, 1 (1955); 川又元夫, 井上幸庰, 工羓

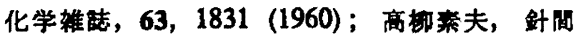
浩, 岩田安弘, 材料, 12, 389 (1963).

2) Y. Takahashi, J. Appl. Polym. Sci., 5, 468 (1961); 高㛢勇三, 田中広司, 世良田弘治, 材 料, 12, 135 (1963).

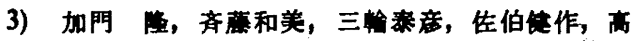
分子化学, 30, 532 (1973).

4) 小川弘正, 田中裕子, 内犦一男, 日本化学会 24 年会新滛予和集, 2144 (1971).

5) 小川弘正, 田中裕子, 山口宗明, プラスヂック

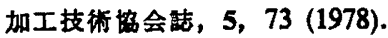

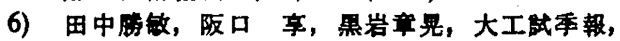
22, 163 (1971).

7) 美浱童夫，小川弘正，吾蒖，日特公 649657 .

8) 小川弘正, 美浱䇅夫, 日本化学会, 日本分析学

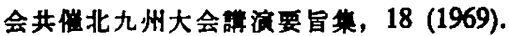

9) 小川弘正, 田中裕子, 高棌高子, 高棌 大, 日 本化学会 26 春期年会新洪予稆集，1856 (1972).

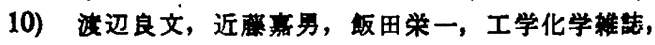
69, 1781 (1966).

11) P.A. Small, J. Appl. Chem., 3, 71 (1953).

12) J.A. Brydson, Plastics, 26 (Dec.), 107 (1961).

13) J. Maláč, V. Altmann, and J. Zelinger, J. Appl. Polym. Sci., 14, 161 (1970).

14）田中腾敏, 未発表. 
Dynamic Mechanical Properties of Blends of Poly (vinyl chloride) and Ethoxymethylmelamine Resin Katsutoshi TANakA*1, Hiromasa OgaWA*1, and Yuko TANAKA*1

*1Government Industrial Research Institute, Osaka (8-31, Midorigaoka 1-chome, Ikeda, $563^{\circ}$ Japan)

Dynamic mechanical properties of the blends of poly (vinyl chloride) (I) with $0 \sim 60 \mathrm{phr}$ of ethoxymethylmelamine resin(II) partially thermo-set, have been examined. The dispersed state of II in I, was unchanged on heating. The modulus of the polyblends was higher, while the $\alpha$ - and $\beta$-peaks in the temperature-tan $\delta$ curves were lowered, than those of $I$ itself. These facts suggest that the cured II acts as a filler. On the other hand, the glass transition temperature $\left(T_{z}\right)$ of I, plasticized with eliminated molecules such as formaldehyde and ethanol, was lowered. These phenomena became more apparent as the II content increased. From these observations, the dynamic mechanical properties of the polyblends can be explained by using filled and plasticized matrix models, assuming the additive contribution of the both components.

KEY WORDS Dynamic Mechanical Property / Poly (vinyl chloride) / Ethoxymethylmelamine Resin / Polyblend / Differential Thermal Analysis (DTA) /

(Received November 13, 1978: Accepted November 25, 1978)

[Kobunshi Ronbunshu, 36 (5), 321-327 (1979)] 